\title{
PENGARUH UNIT PRODUKSI, PRAKERIN, PRESTASI BELAJAR DAN DUKUNGAN KELUARGA TERHADAP KESIAPAN KERJA SISWA SMK NEGERI 10 SURABAYA
}

\author{
Siti Alfiyah Hartati, SMKN 10 Surabaya \\ alfiyahhartati@gmail.com
}

\begin{abstract}
ABSTRAK
Penelitian ini bertujuan untuk mengetahui: kesiapan kerja siswaSekolah Menegah Kejuruan (SMK) di SMK Negeri 10 Surabaya, hubungan dan pengaruh kegiatan praktik unit produksi sekolah, pengalaman praktik kerja industri, prestasi belajar dan dukungan keluarga secara sendiri-sendiri maupun bersama-sama terhadap kesiapan kerja siswa di SMK Negeri 10 Surabaya. Populasi penelitian ini adalah siswa SMK kelas XI dan XII di SMK Negeri 10 Surabaya Tahun Ajaran 20142015 dengan sampel sejumlah 110 siswa. Pengambilan sample menggunakan teknik proporsional cluster random sampling. Hubungan dan pengaruh setiap variabel bebas terhadap variabel terikat dianalisis dengan statistik regresi berganda. Hasil dari analisis diskriptif menunjukkan bahwa indikator masingmasing variabel menunjukkan kriteria yang tinggi. Hasil pengujian hipotesis menunjukkan bahwa terdapat pengaruh secara parsial dari masing-masing variabel bebas terhadap variabel terikat. Demikian juga terdapat pengaruh secara simultan antara kegiatan praktik unit produksi sekolah, pengalaman prakerin, prestasi belajar dan dukungan keluarga terhadap kesiapan kerja. Hal ini menjelaskan bahwa kegiatan praktik di unit produksi sekolah, pengalaman prakerin, prestasi belajar dan dukungan keluarga secara bersama-sama dapat mampu menjelaskan varian kesiapan kerja siswa di SMK Negeri 10 Surabaya.
\end{abstract}

Kata-kata Kunci: Unit Produksi, Prakerin, Prestasi Belajar, Dukungan Keluarga, Kesiapan Kerja Siswa.

\begin{abstract}
This study aims to determine: readiness for working students Vocational High School (SMK) in SMK Negeri 10 Surabaya, and the effect of: the practical activities of production units, the experience of working practices of industrial, academic achievement and family support individually or jointly against job readiness of students in SMK Negeri 10 Surabaya. This study population is vocational students of class XI and XII at SMK Negeri 10 Surabaya Academic Year 2014-2015 with a sample of 110 students. The samples using proportional cluster random sampling technique. Relationships and the influence of each independent variable on the dependent variable was analyzed with multiple regression statistics. The results of descriptive analysis showed that each variable indicators showed high criteria. Hypothesis testing results show that there is a partial effect of each independent variable on the dependent variable. Likewise, there are significant simultaneous production unit between the practical activities of the school, prakerin experience, academic achievement and family support for job readiness. It is clear that the practical activities in the school production
\end{abstract}


units, prakerin experience, academic achievement and family support together may be able to explain variants job readiness of students in SMK Negeri 10 Surabaya.

Keywords: Production Unit, Prakerin, Achievement, Family Support, Student Work Readiness.

\section{PENDAHULUAN}

Pengangguran lulusan SMK jumlahnya adalah 11,24\% dari total jumlah pengangguran. Pengangguran lulusan SMK ini naik tipis dibandingkan posisi Agustus 2013 yang mencapai 11,21\%. Sementara penggangguran bertitel Diploma jumlahnya 6,14\% dari total pengangguran, naik dari Agustus 2013 5,95\%. Pengangguran Sarjana mencapai 5,65\% dari total pengangguran, naik dari Agustus 2013 sebesar 5,39\%. Dia mengaku heran karena banyak lulusan Sekolah Menengah Kejuruan (SMK) yang berstatus pengangguran. Pasalnya, dia menilai lulusan Sekolah Menengah Kejuruan (SMK) harusnya punya kemampuan yang khusus yang dibutuhkan dunia kerja. "Banyak yang lulusan kejuruan itu masih pengangguran," kata Suryamin kepala Biro Pusat Statistik Jakarta (suara merdeka.com, 5 Nopember 2014).

Demikian juga yang terjadi di SMK Negeri 10 Surabaya, berdasarkan hasil penelusuran tamatan tahun kelulusan 2012 khususnya Program Keahlian Perbankan menunjukkan jumlah yang bekerja 47 (61,84\%) orang dan yang belum bekerja 29 orang dari 76 tamanan. Tamatan yang belum bekerja ini disebabkan beberapa hal, diantaranya karena kuliah, menikah, menunggu biaya untuk melanjutkan ke Perguruan Tinggi dan menunggu lowongan pekerjaan. Hal ini menunjukkan Kesiapan Kerja Siswa SMK Negeri 10 Surabaya belum sesuai dengan apa yang diharapkan, seperti yang menjadi misi dari SMK Negero 10 Surabaya yang salah satunya adalah Kerja 70\%, kuliah 15\% dan Wirausaha 15\%.

Kesiapan kerja siswa SMK Negeri 10 Surabaya khususnya kompetensi keahlian Perbankan yang dirasa belum mencapai tarjet sesuai misi SMK Negeri 10 ini mungkin dikarenakan kemampuan siswa yang kurang memenuhi syarat dalam dunia kerja. Diantara penyebab kegagalan dalam misi ini jika dilihat dari fenomena yang terjadi diantaranya unit produksi yang berada di sekolah yang merupakan sarana belajar praktek siswa kurang melibatkan ssiwa secara total dalam pelaksanaan praktek di lapangan. Juga keterlibatan siswa dalam praktek dengan dunia usaha dan dunia industri juga kurang mendapat tempat yang sesuai dengan bidang keahliannya. Hal ini terbukti adanya keluhan dari siswa yang menyatakan bahwa selama pelaksanaan prakerin ada beberapa siswa yang merasa kegiatan prakerin tidak sesuai antara keilmuan yang didapat di bangku sekolah dengan praktek dilapangan dalam hal ini prakerin. Padahal dari unit produksi sekolah dan prakerin diharapkan nantinya siswa mempunyai kemampuan dan bekal yang cukup untuk bekerja sesuai dengan keahliannya.

Bukan itu saja penyebab yang memungkinkan siswa belum siap dalam menghadapi dunia kerja, dukungan orang tua juga dirasa kurang. Ketidaksiapan orang tua untuk melepas anaknya jika bekerja di tempat yang jauh dengan fasilitas dan gaji yang lebih baik, mereka selalu mempertahankan kehendaknya dengan dalih kasihan, meskipun gaji sedikit tetapi dekat dengan orang tua. Padahal dukungan orang tua sangat diharapkan bagi siswa untuk mendapat kehidupan 
yang lebih baik dengan bekerja yang lebih mapan dan sesuai dengan keahliannya.kemudian tentang prestasi belajar siswa juga perlu dipertanyakan karena hasil yang didapatkan sangatlah kurang memuaskan khususnya untuk mata pelajaran yang terkait dengan kompetensi keahliannya.

Tujuan utama SMK/MAK adalah menyiapkan tamatan yang siap bekerja di bidangnya. Berkaitan dengan penyiapan tenaga kerja ini, secara eksplisit disebutkan dalam Peraturan Pemerintah nomor 29 tahun 1990 pada pasar 29 ayat 2, bahwa: "untuk mempersiapkan siswa SMK menjadi tenaga kerja, pada SMK dapat didirikan Unit Produksi yang beropersional secara profesional”. Dari pengertian tersebut jelas bahwa unit produksi sangat turut andil dalam membantu siswa dalam kesiapan untuk bekerja. Untuk itu, khususnya SMK sebagai sekolah kejuruan yang memang mempersiapkan siswanya untuk bekerja harus mampu memberi pengalaman kerja memalui unit produksi yang ada di sekolahnya agar nantinya mampu untuk menguasai kompetensi produktif secara profesional.

Unit Produksi/Jasa Sekolah Menengah Kejuruan ialah suatu proses kegiatan usaha yang dilakukan sekolah/madrasah secara berkesinambungan, bersifat akademis dan bisnis dengan memberdayakan warga sekolah/madrasah dan lingkungan dalam bentuk unit produksi/jasa yang dikelola secara profesional (Dikmenjur, 2007).

Pada proses pembelajaran di SMK, peserta didik mengikuti program pendidikan dan pelatihan (diklat) dengan acuan kurikulum yang sesuai dengan tuntutan dunia kerja setempat dan daerah dimana lulusan diproyeksikan akan bekerja. Dalam pelaksanaan pembelajaran, siswa dapat melaksanakannya di sekolah dan/ atau di dunia kerja. Proses pembelajaran di sekolah dimaksudkan untuk mengembangkan potensi akademis dan kepribadian siswa, menguasai ilmu pengetahuan dan teknologi, sesuai dengan kebutuhan dan perkembangan dunia kerja.

Praktik kerja industri akan menggambarkan keterlibatan siswa dalam suatu pekerjaan yang nyata sesuai dengan bidang keahliannya, selain itu siswa akan memperoleh pengalaman untuk memperluas pengetahuannya tentang dunia kerja. Pelaksanaan Praktik Kerja Industri secara tidak langsung akan memberikan pengetahuan dan pengalaman dalam bekerja. Pengalaman yang diperoleh pada saat melaksanakan praktik industri, selain mempelajari bagaimana cara mendapatkan pekerjaan, juga belajar bagaimana memiliki pekerjaan yang sesuai dengan bakat dan minat yang dimiliki oleh siswa tersebut. Pengalaman dalam hal ini adalah pengalaman yang didapat setelah melaksanakan Praktik Kerja Industri, pengalaman kerja inilah yang akan menentukan kesiapan siswa untuk bekerja, karena di industri siswa diajarkan untuk bekerja sesuai dengan kemampuannya.

Proses pembelajaran/ pelatihan di dunia kerja dimaksudkan agar siswa menguasai kompetensi terstandar, mengembangkan dan menginternalisasi sikap dan nilai professional sebagai tenaga kerja yang berkualitas unggul, baik bekerja pada pihak lain maupun sebagai pekerja mandiri. Sebelum mengaktualisasikannya, maka diperlukan persiapan-persiapan yang meliputi inventarisasi sumber daya pemelajaran dan penilaian kesiapan pembelajaran. Inventarisasi tempat pemelajaran yang sesuai untuk pemelajaran berbasis kompetensi adalah tempat dimana kompetensi yang dipelajari diimplementasikan (dunia kerja sesungguhnya), atau setidak-tidaknya merupakan replika dari kondisi yang sesungguhnya. Prakerin adalah pola penyelenggaraan diklat yang dikelola 
bersama-sama antara SMK dengan industry/asosiasi profesi sebagai institusi pasangan (IP), mulai dari tahap perencanaan, pelaksanaan hingga evaluasi serta sertifikasi yang merupakan satu kesatuan program dengan menggunakan berbagai bentuk alternative pelaksaan". Aspek yang dinilai adalah efektifitas program praktek kerja industri dengan indikator penilaian: perencanaan praktek kerja industri yaitu pemahaman siswa tentang prakerin dan kegiatan pra pakerin, pelaksaaan praktek kerja insutri yaitu kegiatan selama prakerin, evaluasi serta sertifikasi praktek kerja industri yaitu kegiatan setelah prakerin(Dikmenjur, 2008).

Belajar merupakan proses perubahan dalam diri yangdialami oleh setiap individu sejak lahir agar dapat mempertahankan kehidupannya. Pengalamanpengalaman yang dialami oleh masing-masing individu dapat dikatakan sebagai proses belajar, karena dari pengalaman tersebut mampu mengubah sikap atau kepribadian orang tersebut.

Berdasarkan definisi di atas, maka dapat disimpulkan bahwa belajar adalah suatu proses perubahan tingkah laku seseorang yang menyangkut unsur cipta, rasa dan karsa, ranah kognitif, afektif, dan psikomotorik sebagai hasil dari pengalaman sendiri atas pengaruh interaksi terhadap lingkungan dalam memenuhi kebutuhan hidupnya. Proses keberhasilan dalam belajar tentunya akan menjadi tolak ukur keberhasilan dalam pencapaian tujuan pendidikan. Ketika proses belajar dapat berjalan dengan baik, maka dapat dikatakan bahwa hal tersebut dapat memberikan dampak yang positif bagi perkembangan pencapaian tujuan.

Prestasi belajar adalah penilaian hasil usaha kegiatan yang dinyatakan dalam bentuk simbul, angka, huruf maupun kalimat yang dapat mencerminkan hasil yang sudah dicapai oleh setiap anak dalam periode tertentu (Tirtonegoro,2001).

Dukungan adalah suatu upaya yang diberikan untuk orang lain meliputi moral dan material agar orang yang diberikan dukungan menjadi termotivasi dalam melakukan kegiatan (Sarwono, 2003). Menurut Santoso (dalam Zawawi $\mathrm{F}$,2012) dukungan adalah daya upaya untuk membawa sesuatu dan usaha untuk menyokong sesuatu. Dukungan ini biasanya dapat diperoleh dari lingkungan sosial yaitu orang-orang yang dekat, termasuk di dalamnya adalah anggota keluarga, orang tua dan teman.

Family support is a set of beliefs and anapproach to strengthening and empowering families, which will positively affect children's development and learning(Grant \& Ray, 2010).Dari definisi tersebut dapat diartikan bahwa dukungan keluarga adalah seperangkat keyakinan dan pendekatan untuk penguatan dan pemberdayaan keluarga, yang positif akan mempengaruhi perkembangan dan belajar anak-anak. Seperangkat keyakinan dan pendekatan untuk penguatan dan pemberdayaan keluarga maka faktor mental sangat berperan dalam hal ini.

Ciri-ciri peserta didik yang telah mempunyai Kesiapan Kerja adalah bahwa peserta didik tersebut memiliki pertimbangan-pertimbangan sebagai berikut: a) mempunyai pertimbangan yang logis dan objektif, b) mempunyai kemampuan dan kemauan untuk bekerja sama dengan orang lain, ketika bekerja dibutuhkan hubungan dengan banyak orang untuk menjalin kerjasama, c) mampu mengendalikan diri atau emosi, pengendalian diri atau emosi sangat dibutuhkan agar dalam menyelesaikan suatu pekerjaan dapat diselesaikan dengan baik dan benar, d) memilliki sikap kritis, e) mempunyai keberanian untuk menerima tanggung jawab secara individual, f) mempunyai kemampuan beradaptasi dengan 
lingkungan dan perkembangan teknologi, g) mempunyai ambisi untuk maju dan berusaha mengikuti perkembangan bidang keahlian.(Fitriyanto, 2006)

\section{METODE PENELITIAN}

Variabel dalam penelitian ini yang menjadi variabel bebas (variabel independen) yang diteliti yaitu unit produksi $\left(\mathrm{X}_{1}\right)$, Prakerin $\left(\mathrm{X}_{2}\right)$, Prestasi belajar $\left(\mathrm{X}_{3}\right)$ dan Dukungan Keluarga $\left(\mathrm{X}_{4}\right)$. Variabel terikat (variabel dependen) yaitu kesiapan kerja (Y).

Jumlah populasi secara keseluruhan adalah sebanyak 150 siswa kompetensi keahlian perbankan. Untuk pengambilan sampel yang dimaksud maka diperlukan teknik sampling. Dari hasil perhitungan ini maka sampel yang diambil sebanyak 110 siswa. Berdasarkan pada perhitungan tersebut maka diambil sampel dari kelas XI PBK 1 sebanyak 29 siswa, kelas XI PBK 2 sebanyak 27 siswa, kelas XII PBK 1 sebanyak 28 siswa dan kelas XII PBK 2 sebanyak 26 siswa jadi total keseluruhan sampel adalah 110 siswa.

Instrumen yang menggunakan angket dalam penelitian ini yaitu variabel Unit Produksi, Dukungan Keluarga dan Kesiapan Kerja. Berdasarkan perhitungan hasil uji statistik dengan menggunakan bantuan program SPSS didapatkan bahwa dari 13 butir instrument untuk variabel unit produksi semuanya dinyatakan valid. Untuk variabel dukungan keluarga semuanya dinyatakan valid. Untuk variabel kesiapan kerja semuanya dinyatakan valid.

Jika instrument penelitian telah dikatakan valid, selanjutnya pengujian alat pengumpulan data kedua yaitu pengujian reliabilitas instrument. Pengukuran reliabilitas pada penelitian ini menggunakan uji statistik Cronbach Alpha. Instrument dikatakan reliabel jika nilai Cronbach Alpha $>0.60$. Untuk Uji Reliabilitas Variabel Unit Produksihasil perhitungan uji coba kuesioner pada 30 responden kemudian dianalisis menggunakan rumus alpha diperoleh nilai Cronbach Alpha sebesar 0.842. Hasil Cronbach Alpha nilainya lebih besar dari 0.60 , sehingga instrumen yang digunakan dalam penelitian ini reliabel. Untuk Variabel Dukungan Keluargadiperoleh nilai Cronbach"s Alpha sebesar 0.902. Hasil Cronbach Alpha nilainya lebih besar dari 0.60, sehingga instrumen yang digunakan dalam penelitian ini reliabel. Untuk Variabel Kesiapan Kerjadiperoleh nilai Cronbach Alpha sebesar 0.878. Hasil Cronbach Alpha nilainya lebih besar dari 0.60 , sehingga instrumen yang digunakan dalam penelitian ini reliabel.

Teknik analisis data dalam penelitian kuantitatif menggunakan statistik. Dalam penelitian ini dilakukan teknik analisis data dengan menggunakan statistik deskriptif dan statistik inferensial (parametrik) dengan bantuan SPSS. Sedangkan metode yang digunakan dengan menggunakan metode analisis diskriptif dan analisis regresi.

Untuk analisis deskriptif tiap indikator dalam suatu variabel dengan menghitung mean pada masing-masing indikator. Kategori mean pada tiap indikator dalam suatu variabel antara 3,01 sampai 4,00 maka dikategorikan tinggi, antara 2,01 sampai 3,00 dikategorikan sedang dan antara 1,00 sampai 2,00 dikategorikan rendah.

Sedangkan untuk variabel Prakerin (Praktek Kerja Industri) disusun berdasarkan kualifikasi penilaian yang sudah ditetapkan oleh SMK Negeri 10 Surabaya. Untuk rentang nilai antara 91 - 100 dikualifikasikan baik sekali, 70 - 
89 dikualifikasikan baik, 61 - 69 dikualifikasikan cukup, 41 - 60 dikualifikasikan kutang. Dan untuk variabel prestasi belajar disusun berdasarkan predikat yang juga sudah ditetapkan oleh manajemen di SMK Negeri 10 Surabaya. Yaitu untuk rentang 75 - 100 mempunyai predikat Kompeten, 0 - 74 dengan predikat tidak kompeten.

Untuk uji regresi berganda pada penelitian ini yaitu dengan empat variabel bebas/dependen terhadap satu variabel oleh hasil regresi sebagai berikut:

$$
Y=a+b_{1} X_{1}+b_{2} X_{2}+b_{3} x_{1}+b_{4} X_{4}
$$

Sumber: Sugiyono, 2012

\section{HASIL PENELITIAN DAN PEMBAHASAN}

\section{Hasil Penelitian}

Variabel unit produksi terdiri dari beberapa komponen pengukuran indikator yaitu: aspek edukatif, aspek ekonomis, aspek sosial. Dari masing-masing indikator dalam unit produksi dapat diketahui urutan mulai yang teratas adalah aspek edukatif dengan mean 3,30, diikuti oleh aspek ekonomis dengan mean 3,21 dan paling rendah adalah aspek social dengan mean 3,20. Dari subindikator yang memiliki kategori tertinggi yaitu etos kerja yang tinggi dengan mean 3,37 hal ini dapat dilihat keaktifan siswa saat praktik di unit produksi, selalu melaksanakan tugas sesuai dengan jadwal yang sudah ditentukan, selalu mentaati peraturan yang sudah ditetapkan oleh pengurus unit produksi. Sedangkan subindikator dengan nilai terendah yaitu komunikasi aktif secara langsung peserta didik dan masyarakat dengan mean 3,10 hal ini berhubungan keterkaitan siswa dengan berinteraksi langsung dengan masyarakat saat bertugas sebagai Costumer Service.

Variabel Praktik Kerja Industri/Prakerin atau sering disebut diperoleh siswa saat melakukan On The Jor Training (OJT) diukur sejauh mana pengetahuan dan ketrampilan yang diperoleh siswa saat melukan On The Jor Training (OJT) dilihat dari hasil yang diperoleh oleh siswa setelah mereka menyelesaikan OJT. Untuk itu dalam penelitian ini variabel prakerin pengukurannya dengan menggunakan nilai rerata dari evaluasi selama mengikuti OJT (On The Job Training) kelas XI PBK dan XII PBK tahun pelajaran 2014-2015. Secara umum pada variabel prakerin untuk kompetensi keahlian Perbankan SMK Negeri 10 Surabaya dalam kategori baik yaitu sebesar $90 \%$ atau 90 responden. Sedangkan kategori baik sekali terdapat $18 \%$ atau 20 responden. Dengan demikian untuk variabel prakerin hasil yang didapat oleh siswa selama melakukan prakerin mendapatkan predikat secara umum adalah baik.

Variabel prestasi belajar diukur sejauh mana prestasi belajar siswa kompetensi keahlian perbankan yaitu dengan hasil yang diperoleh yaitu berupa nilai yang didalamnya sudah memeperlihatkan perilaku siswa baik dalam bentuk penguasaan pengetahuan (kognitif), keterampilan (psikomotor) dan sikap (afektif). Sedangkan mata pelajaran yaitu mata pelajaran produktif yang terdiri dari seluruh responden pada variabel prestasi belajar yang diperoleh dari hasil rerata nilai mata pelajaran produktif pada kompetensi keahlian Perbankan SMK Negeri 10 Surabaya dalam predikat kompeten yaitu sebesar 100\% atau 110 responden. Dengan demikian dapat disimpulkan bawa seluruh responden dinyatakan 
kompeten sesuai dengan keahlian yang mereka miliki jika dilihat dari hasil nilai mata pelajaran produktif pada sememster genap.

Variabel dukungan keluarga terdiri dari beberapa indikator pengukuran yaitu: dukungan informasional, dukungan penilaian, dukungan instrumental, dukungan emosional. Dari masing-masing indikator dalam variabel dukungan keluarga dapat diketahui urutan mulai yang teratas adalah dukungan informasional dengan mean 3,38, kemudian diikuti oleh dukungan penilaian dengan mean 3,33 kemudian dukungan emosional dengan mean 3,20 kemudian paling rendah adalah dukungan instrumental dengan mean 3,15. Dari subindikator yang memiliki kategori tertinggi yaitu pemberian nasehat dengan mean 3,46 hal ini dilihat dari intensitas orang tua untuk selalu memberikan nasehat terutama untuk urusan pekerjaan yang diinginkan dan keluarga juga membantu mencarikan informasi apapun yang diinginkan sesuai dengan pekerjaan yang diinginkan. Sedangkan kategori terendah yaitu pemberian bantuan tenaga dengan mean 2,89 yaitu berhubungan dengan pemberian bantuan tenaga dari keluarga.

Variabel kesiapan kerja terdiri dari beberapa indikator pengukuran yaitu:r pertimbangan yang logis, kemauan dan kemampuan kerjasama dengan orang lain, mampu mengdalikan diri, sikap kritis, berani menerima tanggungjawab, adaptasi dengan lingkungan dan perkembangan teknologi, ambisi untuk maju dan berusaha mengikuti perkembangan bidang keahlian. Untuk variabel kesiapan kerja peneliti menggunakan angket kepada responden. Untuk variabel kesiapan kerja ada tujuh indikator yang semuanya juga masuk kategori tinggi sesuai dengan range yang sudah ditetapkan. Dari masing-masing indikator berdasarkan urutan teratas yaitu ambisi untuk maju dan berusaha mengikuti perkembangan bidang keahlian dengan mean 3,36 kemudian diikuti oleh Pertimbangan yang logis dan obyektif dengan mean 3,35 kemudian kemampuan beradaptasi dengan lingkungan dan perkembangan teknologi dengan mean 3,33 kemudian kemauan dan kemampuan kerjasama dengan orang lain dengan mean 3,29 kemudian memiliki sikap kritis dengan mean 3, 21 kemudian mampu mengendalikan diri dan emosi dengan mean 3,19 kemudian yang paling rendah adalah keberanian untuk menerima tanggungjawab dengan mean 3,17.Dari indikator yang memiliki kategori tertinggi yaitu ambisi untuk maju dan berusaha mengikuti perkembangan bidang keahlian dengan mean 3,36 hal ini dapat dilihat darikegemaran siswa dalam membaca buku terutama yang terkait dengan bidang keahliannya masing-masing, siswa suka mengikuti kegiatan atau pelatihan yang sesuai dengan bidang keahliannya, dan siswa suka dengan hal-hal baru yang menunjang keilmuannya. Sedangkan indikator dengan nilai terendah yaitu keberanian untuk menerima tanggungjawab dengan mean 3,17 hal ini berhubungan dengan keberanian siswa untuk menerima pekerjaan yang biasanya disegani oleh teman kerja yang lain.

Berdasarkan hasil analisis yang dilakukan untuk variabel bebas (independent variable) unit produksi, prakerin, prestasi belajar dan dukungan keluarga dengan variabel terikatnya (dependent variable) kesiapan kerja diperoleh hasil output sebagai berikut: 


\section{Coefficients $^{\mathrm{a}}$}

\begin{tabular}{|l|r|r|r|r|r|}
\hline \multirow{2}{*}{ Model } & \multicolumn{2}{|c|}{$\begin{array}{c}\text { Unstandardized } \\
\text { Coefficients }\end{array}$} & $\begin{array}{c}\text { Standardized } \\
\text { Coefficients }\end{array}$ & \multicolumn{1}{c|}{} \\
\cline { 2 - 4 } & \multicolumn{1}{c|}{$\mathrm{B}$} & Std. Error & \multicolumn{1}{c|}{ Beta } & \multicolumn{1}{c|}{$\mathrm{t}$} & \multicolumn{1}{c|}{ Sig. } \\
\hline (Constant) & 29.283 & 11.928 & & 4.617 & .019 \\
Unit Produksi & .462 & .117 & .411 & 3.933 & .000 \\
Prakerin & .329 & .261 & .243 & 2.480 & .032 \\
Prestasi Belajar & .372 & .126 & .353 & 2.570 & .030 \\
Dukungan Keluarga & .338 & .291 & .244 & 2.421 & .025 \\
\hline
\end{tabular}

a. Dependent Variable: Kesiapan Kerja

Sumber: Data diolah (2015)

Dari hasil tersebut dapat diperoleh analisis regresi linear berganda, sebagai berikut:

\section{$Y=29,283+0,462 X_{1}+0,329 X_{2}+0,372 X_{1}+0,338 X_{4}$}

Dari persamaan regresi di atas menjelaskan bahwa:

a. Konstanta (a) yang dihasilkan sebesar 29,283 hal ini menunjukkan bahwa besarnya kesiapan kerja siswa adalah 29,283 jika variabel unit produksi, prakerin, prestasi belajar dan dukungan keluarga dianggap nol (0) atau ditiadakan maka besarnya kesiapan kerja (Y) sebesar 29,283.

b. Koefisien regresi pada variabel unit produksi adalah positif sebesar 0,462 artinya jika variabel unit produksi $\left(\mathrm{X}_{1}\right)$ naik satu satuan maka variabel kesiapan kerja $(\mathrm{Y})$ akan naik sebesar 0,462 satuan dengan asumsi bahwa variabel yang lain prakerin, prestasi belajar dan dukungan keluarga adalah konstan.

c. Koefisien regresi pada variabel prakerin adalah positif sebesar 0,329 artinya jika variabel prakerin $\left(\mathbf{x}_{\mathbf{2}}\right.$ ) naik satu satuan maka variabel kesiapan kerja (Y) akan naik sebesar 0,329 satuan dengan asumsi bahwa variabel yang lain unit produksi, prestasi belajar dan dukungan keluarga adalah konstan.

d. Koefisien regresi pada variabel prestasi belajar adalah positif sebesar 0,372 artinya jika variabel prestasi belajar $\left(\mathbf{x}_{\mathbf{\rho}}\right)$ naik satu satuan maka variabel kesiapan kerja (Y) akan naik sebesar 0,372 satuan dengan asumsi bahwa variabel yang lain unit produksi, prakerin dan dukungan keluarga adalah konstan

e. Koefisien regresi pada variabel dukungan keluarga adalah positif sebesar 0,338 artinya jika variabel dukungan keluarga $\left(\mathbf{x}_{\mathbf{4}}\right.$ ) naik satu satuan maka variabel kesiapan kerja (Y) akan naik sebesar 0,338 satuan dengan asumsi bahwa variabel yang lain unit produksi, prakerin, dan prestasi belajar adalah konstan.

Uji hipotesis secara simultan menunjukkan nilai Fhitung yaitu 5.939, sedangkan nilai $\mathrm{F}_{\text {tabel }}$ dapat diperoleh dengan menggunakan tabel $\mathrm{F}$ dengan derajat bebas (df) Residual (sisa) yaitu 105 sebagai df penyebut dan df Regression (perlakuan) yaitu 4 sebagai df pembilang dengan tarap siginifikan 0,05 , sehingga diperoleh nilai $\mathrm{F}$ tabel yaitu 2,4542. Karena Fhitung $5.939>\mathrm{F}$ tabel 2,4542 maka model signifikan.Berdasarkan nilai signifikan, terlihat pada kolom sig yaitu 0,000 
jadi signifikasi kurang dari 0,05, maka Ho ditolak pada derajat kepercayaan 5\%, dengan kata lain Ha diterima, sehingga hipotesis 5 diterima yang menyatakan bahwa ada pengaruh antara variabel unit produksi $\left(\mathrm{X}_{1}\right)$, prakerin $\left(\mathrm{X}_{2}\right)$, prestasi belajar $\left(\mathrm{X}_{3}\right)$ dan dukungan orang tua $\left(\mathrm{X}_{4}\right)$ terhadap kesiapan kerja $(\mathrm{Y})$ di SMK Negeri 10 Surabaya.

Untuk uji hipotesis secara parsial (uji t) hasil analisismenunjukkan hasil untuk variabel unit produksi, dapat dilihat bahwa nilai $\mathrm{T}_{\text {hitung }}$ untuk variabel unit produksi yaitu 3.933, pada $\mathrm{T}_{\text {tabel }}$ dengan db 110 dan taraf signifikan 0,05 diperoleh 1,9817, karena $T_{\text {hitung }}>\mathrm{T}_{\text {tabel }}$ maka Ho ditolak dan Ha diterima. Dengan demikian hipotesis 1 diterima dan hasilnya ada pengaruh antara variabel unit produksi $\left(\mathrm{X}_{1}\right)$ terhadap kesiapan kerja (Y). Untuk variabel prakerin dapat dilihat bahwa nilai $\mathrm{T}_{\text {hitung }}$ untuk variabel prakerin yaitu 2.480 pada $\mathrm{T}_{\text {tabel }}$ dengan $\mathrm{db} 110$ dan taraf signifikan 0,05 diperoleh 1,9817, karena $\mathrm{T}_{\text {hitung }}>\mathrm{T}_{\text {tabel }}$ maka Ho ditolak dan Ha diterima. Dengan demikian hipotesis 2 diterima dan hasilnya ada pengaruh antara variabel prakerin $(\mathrm{X}=)$ terhadap kesiapan kerja $(\mathrm{Y})$.Untuk variabel prestasi belajar dapat dilihat bahwa nilai $T_{\text {hitung }}$ untuk variabel prestasi belajar yaitu 2.570 , pada $\mathrm{T}_{\text {tabel }}$ dengan $\mathrm{db} 110$ dan taraf signifikan 0,05 diperoleh 1,9817, karena $\mathrm{T}_{\text {hitung }}>$ $\mathrm{T}_{\text {tabel }}$ maka Ho ditolak dan Ha diterima. Dengan demikian hipotesis 3 diterima dan hasilnya ada pengaruh antara variabel prestasi belajar $\left(\mathrm{X}_{3}\right)$ terhadap kesiapan kerja (Y).Untuk variabel dukungan keluarga dapat dilihat bahwa nilai Thitung

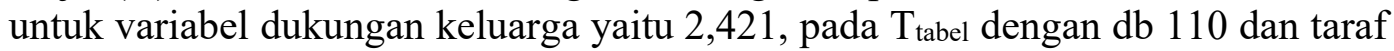
signifikan 0,05 diperoleh 1,9817, karena $\mathrm{T}_{\text {hitung }}>\mathrm{T}_{\text {tabel }}$ maka Ho ditolak dan Ha diterima. Dengan demikian hipotesis 4 diterima dan hasilnya ada pengaruh antara variabel dukungan keluarga $\left(\mathrm{X}_{4}\right)$ terhadap kesiapan kerja $(\mathrm{Y})$.

Untuk pembahasan pengaruh masing-masing variabel bebas terhadap variabel terikat maupun pengaruh variabel bebas secara bersama-sama terhadap variabel terikat adalah sebagai berikut:

\section{Pengaruh Unit Produksi Terhadap Kesiapan Kerja Siswa SMK Negeri 10 Surabaya}

Berdasarkan analisis data yang telah dilakukan melalui regresi berganda, diperoleh hasil bahwa ada pengaruh positif unit produksi terhadap kesiapan kerja siswa SMK Negeri 10 Surabaya. Hal ini berarti variabel unit produksi menunjukkan nillai positif, maka variabel unit produksi memiliki hubungan yang searah dengan kesiapan kerja yaitu semakin baik unit produksi yang ada di sekolah semakin baik pula kesiapan kerja siswa.

Hasil penelitian yang sudah dilakukan pada variable unit produksi yaitu indikator aspek edukatif yaitu sub indikator etos kerja yang positif terkait dengan variable kesiapan kerja pada indikator memiliki sikap kritis. Untuk indikator aspek ekonomis pada subindikator memupuk dan menumbuhkan jiwa wirausaha, sarana pelatihan wirausaha dan bisnis dunia kerja terkait dengan variable kesiapan kerja pada indikator mempunyai pertimbangan yang logis dan obyek, mampu mengendalikan diri dan emosi, memiliki sikap kritis, mempunyai keberanian untuk menerima tanggungjawab secara individual. Untuk indikator aspek sosial pada subindikator semangat dan kebersamaan terkait dengan variable kesiapan kerja pada indikator mempunyai kemampuan dan kemauan untuk bekerjasama dengan orang lain. Pada subindikator komunikasi aktif secara langsung peserta didik dan masyarat terkait dengan 
variable kesiapan kerja pada indikator mempunyai kemampuan beradaptasi dengan lingkungan.

\section{Pengaruh Prakerin Terhadap Kesiapan Kerja Siswa SMK Negeri 10} Surabaya

Berdasarkan analisis data yang telah dilakukan, diperoleh hasil bahwa ada pengaruh positif prakerin terhadap kesiapan kerja siswa SMK Negeri 10 Surabaya. Dengan demikian dapat didiskripsikan bahwa semakin baik prakerin yang dilakukan siswa maka kesiapan kerja bagi siswa juga akan semakin baik.

Dari hasil penelitian mengenai prakerin yang menunjukkan bahwa hasil yang diperoleh siswa selama melaksanakan prakerin dengan kategori baik. Dengan demikian prakerin sangat berpengaruh pada kesiapan kerja. Untuk prakerin ada dua aspek yang nilai yaitu aspek teknis yang terkait dengan ketrampilan yang berkait dengan keilmuan seperti menghitung mutasi rekeningkoran, menata dan memelihara kelengkapan file kredit, setor, trannfer dan valas, membat slip dan surat. Dari hasil aspek teknis semua siswa menunjukkan hasil yang pada umunya baik. Dan untuk aspek non teknis yaitu terkait dengan afektif yaitu penilaian sikap selama melaksanakan prakerin dilihat dari disiplin, kerjasama, insisiatif tanggungjawab, kebersihan, kejujuran dan kerajinan.

Dari hasil penelitian untuk aspek non teknis ini menunjukkan bahwa selama siswa melaksanakan prakerin mendapat nilai yang baik. Karena baik aspek teknis dan non teknis menunjukan hasil yang baik maka kesiapan kerja siswa baik. Untuk aspek non teknis pada variable prakerin terkait dengan variable kesiapan kerja pada indikator mempunyai kerjasama dengan orang lain, memiliki sikap kritis, mempunyai keberanian untuk bertaggungjawab.

3. Pengaruh Prestasi Belajar Terhadap Kesiapan Kerja Siswa SMK Negeri 10 Surabaya

Berdasarkan analisis data yang telah dilakukan, diperoleh hasil bahwa ada pengaruh positif prestasi belajar terhadap kesiapan kerja siswa SMK Negeri 10 Surabaya. Dengan demikian dapat didiskripsikan bahwa semakin baik prestasi belajar yang diperoleh siswa maka kesiapan kerja bagi siswa juga akan semakin baik.

Dari hasil penelitian mengenai prestasi belajar siswa SMKN 10 jurusan Perbankan kelas XI dan XII selama semester genap tahun pelajaran 20142015 menunjukkan hasil yang baik, maka siswa tersebur dinyatakan kompeten dibidangnya. Oleh karena prestasi belajar dari responden mendapat nilai yang baik maka untuk kesiapan kerja juga menunjukkan baik pula. Dikarekan penilaian yang terkait dengan prestasi belajar ini adalah mata pelajaran produktif yaitu pelajaran yang menunjukkan kompetensi yang dimiliki siswa maka prestasi yang menunjukkan kompeten berarti siswa juga kompeten dibidangnya. Dengan demikian prestasi belajar mempengaruhi kesiapan kerja.Untuk variabel prestasi belajar terkait dengan variabel kesiapan kerja pada indikator dan salah satunya adalah dengan mengikuti perkembangan bidang keahliannya. Dengan mengikuti mata pelajaran yang disampaikan disekolah berarti siswa tersebut selalu mengikuti perkembangan ilmu sesuai dengan bidang keahliannya. Juga terkait dengan indikator mempunyai kemampuan dan kemauan untuk bekerjasama dengan orang lain, 
dikarenakan dalam mengikuti pelajaran ada tugas-tugas yang mengharuskan sisa untuk bekerja secara berkelompok, sehingga kerjasama yang solid sangat diperlukan.

\section{Pengaruh Dukungan Keluarga Terhadap Kesiapan Kerja Siswa SMK Negeri 10 Surabaya}

Berdasarkan analisis data yang telah dilakukan, diperoleh hasil bahwa ada pengaruh positif dukungan keluarga terhadap kesiapan kerja siswa SMK Negeri 10 Surabaya. Dengan demikian dapat didiskripsikan bahwa semakin baik dukungan keluarga terhadap anaknya dalam hal ini siswa maka kesiapan kerja bagi siswa juga akan semakin baik.

Untuk indikator dukungan informasional terkait dengan variable kesiapan kerja pada indikator mampu mengendalikan diri atau emosi, mempunyai keberanian untuk menerima tanggungjawab secara individual. Untuk indikator dukungan emosional terkait dengan variable kesiapan kerja pada indikator mampu mengendalikan diri atau emosi.

5. Pengaruh Unit Produksi, Prakerin, Prestasi Belajar dan Dukungan Keluarga Terhadap Kesiapan Kerja Siswa SMK Negeri 10 Surabaya

Berdasarkan penelitian ini diperoleh hasil bahwa unit produksi, prakerin, prestasi belajar dan dukungan keluarga secara simultan berpengaruh terhadap kesiapan kerja siswa SMK Negeri 10 Surabaya. Dari hasil yang sudah didapat mempunyai arti bahwa unit produksi, prakerin, prestasi belajar dan dukungan keluarga secara bersama-sama berpengaruh terhadap kesiapan kerja. Unit produksi yang baik, prakerin yang baik, prestasi belajar yang baik dan dukungan keluarga yang baik akan memperngaruhi kesiapan kerja yang baik pula pada diri siswa.

Berdasarkan analisis data secara simultan diperoleh hasil yang signifikan untuk variabel unit produksi, prakerin, prestasi belajar dan dukungan keluarga secara bersama-sama berpengaruh terhadap kesiapan kerja siswa. Dengan demikian secara simultan ada pengaruh antara variabel unit produk ${ }^{\text {: }}$ prakerin, prestasi belajar dan Dukungan orang tua secara bersama-sa] terhadap kesiapan kerja di SMK Negeri 10 Surabaya.

\section{SIMPULAN}

Berdasarkan hasil penelitian dan pembahasan hasil penelitian yang telah dilakukan dapat disimpulkan bahwa: a) ada pengaruh yang signifikan dan positif antara unit produksi yang ada di sekolah terhadap kesiapan kerja siswa SMK Negeri 10 Surabaya. Dengan demikian menunjukkan bahwa jika unit produksi semakin baik maka kesiapan kerja siswa juga semakin baik; b) ada pengaruh yang signifikan dan positif antara prakerin terhadap kesiapan kerja siswa SMK Negeri 10 Surabaya. Dengan demikian menunjukkan bahwa jika siswa saat melaksanakan prakerin dengan dunia usaha dan industri semakin baik maka kesiapan kerja juga semakin baik; c) ada pengaruh yang signifikan dan positif antara prestasi belajar yang didapat siswa terhadap kesiapan kerja siswa SMK Negeri 10 Surabaya. Dengn demikian menunjukkan bahwa jika siswa mendapatkan hasil yang semakin baik dalam prestasi belajar maka kesiapan kerja jugasemakin baik; d) ada pengaruh yang signifikan dan positif antara dukungan keluarga terhadap kesiapan kerja. Dengan demikian menunjukkan bahwa jika dukungan keluarga semakin 
baik maka kesiapan kerja juga semakin baik; e) ada pengaruh secara simultan unit produksi, prakerin, prestasi belajar dan dukungan keluarga secara bersama-sama berpengaruh terhadap kesiapan kerja. Dengan demikian unit produksi yang baik, prakerin yang dilakukan dengan sungguh-sungguh, prestasi belajar yang baik serta mendapat dukungan penuh dari keluarga maka siswa akan lebih siap bekerja setelah lulus.

\section{DAFTAR RUJUKAN}

Awaludin Baiti Ahmad, Sudji Munadi. 2014. "Pengaruh Pengalaman Praktik, Prestasi Belajar Dasar Kejuruan dan Dukungan Orang Tua Terhadap Kesiapan Kerja Siswa SMK”. (online),http://journal.uny.ac.id/index.php/jpv/article/view/2543. Jurnal Pendidikan Vokasi. Vol 4, No 2, Hal 164-180. UNY. Yogyakarta. Diakses tanggal 17 Maret 2015.

Barnett Kate, Robin Ryan. 2005. "Vocational education and training in Australian schools: Issues for practitioners". (online),http://iej.cjb.net. International Education Journal. ERC2004 Special Issue, Vol 5, No 5, page 89-104. Shannon Research Press. Australia. Diakses tanggal 17 Maret 2015.

DEPDIKNAS. 2007. Pedoman manajemen unit produksi/jasa sebagai sumber belajar siswa dan penggalian dana pendidikan persekolahan.

Dikmenjur. 2008. Kurikulum SMK. Jakarta. Depdiknas.

Dirjen Peningkatan Mutu Tendik. 2007. Pedoman Manajemen Unit Produksidan Jasa Sebagai Sumber BelajarSiswa Dan Penggalian PendanaanPendidikan. Jakarta: Depdiknas.

Dirmenjur. 2007. Program SMK 2007. Jakarta. Depdiknas.

Fitriyani Meni, Sukirman dan Nurhasan Hamidi. 2014. "Upaya Peningkatan Kesiapan Kerja Peserta Didik Lulusan Sekolah Menengah Kejuruan di Kabupaten Karanganyar (Studi Kasus di SMK Negeri 1 Karanganyar)".(online),http://jurnal.fkip.uns.ac.id/index.php/ekonomi/articl e/view/4180. Jurnal Pendidikan UNS. Vol 2, No 2, hal 97- 108. UNSPendidikan Ekonomi-BKK Akuntansi. FKIP UNS. Surakarta. Diakses tanggal 17 Maret 2015.

Fitriyanto, A. 2006. Ketidakpastian Memasuki Dunia Kerja Karena Pendidikan. Jakarta. Rineka Cipta.

Grant, Kathy B. \& Ray, Julie A. 2010. Home, School, and Community Collaboration. United Stae Of America. SAGE Publication, Inc.

Hasbullah. 2006. Dasar-Dasar IlmuPendidikan (umum dan agama islam).Jakarta: Rajawali Pers.

Kepmendikbud.1992. Sekolah Menengah Kejuruan. Jakarta.

Kepmendikbud. 1997. Pelaksanaan Pendidikan Sistem Ganda. Jakarta.

Muktiani Eka Evi. 2014. "Pengaruh Praktik Kerja Industri dan Prestasi Akademik Mata Diklat Produktif Akuntansi Terhadap Kesiapan Kerja Siswa Kelas XI Program Keahlian Akuntansi SMK Nasinal Pati Tahun Pelajaran 2012/2013".(online),http://journal.unnes.ac.id/sju/index.php/eeaj. Economic Education nalysis Journal Vol. 3, No. 1, hal 166-172. Pendidikan Ekonomi FE-Unnes. Semarang. Diakses tanggal 15 Maret 2015. 
Nota Laura, Lea Ferrari, V Scott H Solberg and Salvatore Soresi. 2007. "Career Search Sel-Efficasy, Family Support, and Carrer Indecision With Italian Youth". (online), http://jca.sagepub.com/cgi/content/abstract/15/2/181. Journal of Career Assesment, Vol 15, No 2, page 181-193. University of WisconsinMilwaukee." Diakses tanggal 17 Maret 2015.

Rusmani, Moerdiyanto. 2012. "Pelaksanaan Unit Produksi Pada Sekolah Menengah Kejuruan Negeri Kelompok Bisnis dan Manajemen". (online), http://journal.uny.ac.id/index.php/jpv/article/view/1041. Tesis. Program Pascasarjana UNY. Diakses tanggal 17 Maret 2015.

Sarwono. 2003. Psikologi Remaja. Jakarta: PT Raja Gravindo Persada.

Stanley Gordon and Robert G. MacCann. 2009. "Incorporating specific training into school education: enrolment and performance trens in a senior secondary system".(online), http://www.informaworld.com. Journal of Vocational Education and Training, Vol 61, No 4, page 459-466. Oxford Univercity Centre fir Educational Assesment, Oxford. UK. Diakses tanggal 17 Maret 2015.

Sugiyono. 2012. Metode Penelitian Bisnis. Cetakan ke-16. Bandung: Alfabeta.

Sugiyono. 2014. Metode Penelitian Kombinasi (Mixed Methods). Cetakan ke-6. Bandung: Alfabeta.

Tirtonegoro, Sutratinah. 2001. Penelitian hasil belajar mengajar. Surabaya: Usaha Nasional

UNESA. 2014.Pedoman Penulisan Tesis dan Desertasi Program Pasca Sarjana. Surabaya.

UU Republik Indonesia. 2003. Sistem Pendidikan Nasional. Jakarta

Zawawi F, Zam-zam.2012. "Pengaruh Unit Produksi, rakerin, dan Dukungan Keluarga Terhadap Kesiapan Kerja Siswa SMK”. (Online), http://eprints.uny.ac.id/8493/1/1\%20\%2010702259024. Jurnal Pendidikan Vokasi. Vol 2, Nomor 3 hal 397-409. Tesis. Program Pascasarjana UNY. Diakses tanggal 15 Maret 2015. 